\title{
Analysis of the Public Policy of Border Protection in the Security AGENDA OF THE MINISTRY OF THE INTERIOR OF THE CZECH REPUBLIC (FROM 2014 TO MARCH 2017)
}

\author{
Ondřej Stulík \\ University of West Bohemia, Faculty of Philosophy and Arts, \\ Department of Political Science and International Relations, \\ Jungmannova 1, 32300 Pilsen, Czech Republic \\ e-mail: stulik@kap.zcu.cz
}

\begin{abstract}
This paper deals with public policies of security in the Czech Republic. There are many actors in the Czech Republic who speak out on these types of policies; however, in terms of general awareness and executive powers established in legal regulations, the Ministry of the Interior of the Czech Republic is one of the most important institutions dealing with this matter. This actor is responsible not only for carrying out its executive role, but also has a strong role in the preparation of legislative public documents. This paper focuses on the creation and contextual framing of the narrative of the Ministry of the Interior of the Czech Republic (MICR) in the current issue of the so-called migrant crisis, beginning with the creation of the current government in March 2017. Contextual relationships toward the policy of border protection and the meaning of border crossings as a security tool for ensuring the internal security of the Czech Republic are studied. The purpose of the article is to describe and conceptualize the positions of MICR in creating public policies of border control, as the context determined by creating these policies in turn creates the shape of its own priorities for possible public discussion and the control of public institutions.
\end{abstract}

\section{Keywords}

Border protection; Interior security; Migration; Ministry of the Interior of the Czech Republic; Public policy analysis.

\section{Introduction}

The shape of public policies in the Czech Republic, similarly to other democratic states, is formed by the local political culture and the specific ways in which the democratic political system is set up. The political environment (polity) and the mechanisms for shifting the democratic will of the people (politics) significantly impact the possibilities for developing an associative public, including tools for exercising civic activism in a broader sense. This, however, is an idealistic notion that stems from the philosophy of republicanism, which at present is being developed through various approaches. These approaches, for example, include the deliberative or radical approach to democracy $[29,30]$. Other approaches, such as the reductionist approach, which stems from libertarianism, do not thematize the public sphere independently and understand this sphere as a part of the market [31, 32]. Every researcher may choose from these two (or other) directions because both possess the same etymological approach. Additionally, the situation is made more complex by the fact that each direction has many sub-directions that react to one another and come into mutual contradiction. This paper draws on the perspective of Mouffe and Laclau, who perceive the civil (and sometimes also public) discourse as a space full of symbols that create the entire 
mass culture [30]. In a democratic state, mass culture may be criticized. Specific critique may be realized by unveiling individual discursive practices of symbolic representation and, primarily, the methods in which public policies are created. This includes the critical approach applied in this paper, which can be put into the wider context of post-structuralism focused on social symbols (including words and their meanings), which help us understand and classify the world of expressed values [33].

The political environment, political processes, and concrete policies are dependent on one another and cannot be divided, because their meaning is created by context representing the relevant symbols [1]. An expression of this "interconnectedness" can be found in examples in which a certain policy evokes a general reaction in the political public and thus becomes a dominant topic by shaking the foundations of the political environment or its normative structure. At this moment, it becomes a certain beacon that attracts the attention of political analysts (and others) and does not strongly depend on the degree of association and participation in public space, but rather on the simple existence of this space - otherwise, the policy would have no place to resonate. At the same time, the rule applies that a democratic political culture cannot exist without concern for the political environment (at least via the act of voting) and, without a democratic political culture, political processes would be useless, as they would not need to protect the interests of the people (regardless of our definition of them). Specific policies are the catalyzer of public discussion and follow the rules of political culture and its basic normative reflection, which is the reflection of legitimacy. The policies that evoke discussions deserve all the more attention, as they point out upheavals in the values of the whole political environment and possible upheavals in legitimacy.

One of these policies that at present is causing such an upheaval in the public sphere and is contributing to a wider discussion on values is the immigration policy of the Czech Republic. The media widely covered this policy and immigration in general, and dealt with topics such as the selection of a multicultural paradigm, forms of integration and assimilation, relocation quotas, the economic crisis, the international conflict primarily in Syria, etc. The so-called immigration crisis reflects the practical effects of the current immigration policy of the Czech Republic in the same way that the institutions of the Czech Republic are forced to formally react to these effects. The form of the reaction and the field of public policies vary according to the character of the policy and the definition of the issue that steps into public policy.

The ways in which the issue is understood by various actors is the first field we should focus on in the attempt to describe the roots of the policy's controversy and why it is causing an upheaval in values. The definition of the problem is different for every actor, as each one has their own pre-understanding of the given issue; each actor works off of different value positions and relies on a different "story". The description of public policy is linked to the discursive understanding of this policy by each actor, which is reflected both in the shape of strategic decisions that define objectives on pressing issues and in the acceptance of specific formal regulations in the form of legislative measures. The formation of policy is thus dependent on values and their symbolic representation. Various "stories" can be revealed thanks to the analysis of the policy or meaning that is hidden within them. The revealed meaning, which at first glance is not necessarily evident and acknowledged by the actor, is then a valuable finding for public discussion and evaluation of how public policies are established in the field of security. Therefore, this study specifically deals with a type of creation of public policies as storylines [34].

A specific issue that this paper focuses on is the analysis of the shape of Czech security policies in the context of the so-called immigration crisis. The purpose of this research at present resounds in both continental and Anglo-Saxon political science tradition. There exists current research $[38,39,40]$ that can be elaborated upon, even though the specific topic of 
this study (see below) is specific. The research of security and migration, however, is a broader phenomenon and was not created during the current and so-called migration crisis, proof of which can be found in a number of other studies $[35,36,37]$ in various social science fields. Contrary to these studies, however, this paper focuses specifically on analyzing the creation of public policies of a security character with a selected actor representing the "hard power" of the state. The very concrete purpose of the paper is to describe and conceptualize the positions of the Ministry of the Interior of the Czech Republic (further referred to as MICR) in creating public policies of border protection. The interest in the practical impacts of applying population protection stems from efforts toward expanding the information quality of the functions of the state via means of agenda terms of the MICR in the period in question. Through the interpretation of communication mechanisms (and their content), we can demonstrate the narrative form of the legitimizing function of MICR, i.e. the defense of its own position via defining a problem through strategic public policy documents, legislative measures, and press releases. To conclude this introduction, it should be mentioned that there are two reasons for narrowing the analysis to the subject of state borders. The first is the importance of the Act on the Protection of State Borders and the amendment of related laws (Czech Zákon o ochraně státních hranic a o změně souvisejících zákonů) and the relatively controversial character of the policy of closing state borders as the last possibilities of fulfilling the instrumental function of the state in the field of security.

\section{$1 \quad$ Research Objectives}

The overall context between the phenomenon of migration and the reaction to it on the part of MICR is expressed in the narrative of MICR's public policies. The narrative created by MICR is the field of interest of this study, as it creates the specific discursive practices via which MICR forms and formulates public policies. Specific discursive practices provide the space to assess how public policies are created, reveal the dominant tools for their creation, and also provide room for uncovering the priorities of the state (i.e. its position) in the field of security. The analysis of the method of creating and presenting public policies is this paper's specific contribution to broader research on the relationship between the sovereignty of a nation state, the actions of the European Union, and the state's presentation of the phenomenon of security, which has a strong potential for strengthening the unity of citizens and the state. The goal of this article is to reveal the tendencies in creating public policies as storylines in reaction to the studied issue of migration and the research goal of studying national borders.

The issue studied here is the phenomenon of migration in regard to the security of the Czech Republic, which is dealt with executively by MICR. The research object is security in regard to the goal of mapping the context of the migration narrative in policies dealing with fulfilling the function of MICR's ensuring security. The period of the study encompasses the election period of the Chamber of Deputies of the Parliament of the Czech Republic, specifically from the beginning of 2014 to March 2017. This paper focuses on the policies that are linked to the referential research object of borders and border crossings.

\section{Research Methods and Empirical Data Collection}

\subsection{Research Methods}

Content analysis [2, 3, 4, 5], with the use of various principles of frame analysis [6], constitutes the method of fulfilling the set goal. Both methods combine the quantitative (i.e. the number of occurrences of studied expressions) and the qualitative standpoint (the hermeneutic interpretation of the resulting context) [7,8]. The specific method can be divided into several steps that were taken during analysis. 
Firstly, the empirical data collection (see below) was searched for using MaxQda (version 11; "advanced text analysis" function for all words that contained "-secur-" [Czech "-bezp-"] (the necessary part of the word "security") and "-bord-" [Czech "-hran-"] (the necessary part of the word "border"). The justification for searching for these expressions stems from the goal stated above. The selection was narrowed to the mutual occurrence of these two expressions in at least three successive sentences in order for the link and use of these expressions to be clear in one context. This selection was then summarized and automatically encoded by a program into one mutual category (marked with one code).

Secondly, the acquired codes were sorted according to frequency in various documents that were a part of the empirical data collection. At the same time, codes were sorted and created according to open coding $[4,9]$ by means of identifying differing or similar contexts. Thanks to open coding, four main categories of code were created: "security and migration" [Czech bezpečnost a migrace], "protection and control of EU borders" [Czech ochrana a kontrola hranic EU], "border control" [Czech hranični kontroly] and "crime across borders" [Czech kriminalita pres hranice]. Codes were created not only with regard to the contexts listed in the documents, but also according to a logical framework that included tracking the overarching issue of migration and the research object (i.e. security), studying the context in terms of the reference object (i.e. the borders on a state and supranational level), and the supplemental category of cross-border crime.

Thirdly, contextual segments were interpreted in regard to the narrative, code, and document in which they occurred. Part of the interpretation was the reconstruction of the overall narrative of security and migration in regard to the public policy of public borders, including declared dominant practices and tendencies. This is all done in various forms including accessible legislative documents and the defense of individual courses of action that strive to fulfill public policies.

\subsection{Empirical Data Collection}

Empirical data collection is composed of three spheres of documents that were used to fulfill the goals of this study. The first sphere is represented by public documents that commonly serve to process short-term and medium-term goals and the strategies of their implementation in terms of possibilities. Strategic documents offer a basic concept of the direction of MICR's policy in dealing with migration. The second sphere is created by legislative public documents in the form of bills that MICR presented for government negotiations [10]. If these bills were passed by government, they then became a government bill that would be passed on for approval or refusal to the Chamber of Deputies of the Parliament of the Czech Republic. Such a norm could become a public policy of a binding character and would thus be a wholly visible tool for dealing with migration. The final sphere of documents is made up of MICR's press releases during the whole studied period in which an occurrence of the given expressions was observed. On a general level, press releases are advocacy tools for defending MICR's actions. The meaning of these releases is thus rooted in the commentary of the creation and realization of outward policies and thus these press releases significantly add to the complex concept of the ideological and value principles of policies. The selection of all documents was carried out by searching for key words on websites that were founded or cofounded by MICR. All publicly available documents that were found were also included. The ODok [11] portal was used for legislative public documents.

Selected strategies include "The Migration Policy Strategy of the Czech Republic" (Czech Strategie migračni politiky České republiky), which was published by MICR with the support of the European Union and in cooperation with the European Migration Network, which is an international network of national contact points established and financed by the European 
Commission according to the Council Decision from 2008 (2008/381/ES). The purpose of this network is to provide objective, reliable and current information in the field of migration [12]. The national department of the network in the Czech Republic was established under MICR, specifically the Department for Asylum and Migration Policy of the Ministry of the Interior [13]. The Migration Policy Strategy of the Czech Republic is a 24-page document (the number of pages is not normalized) containing the principles of migration policy divided into chapters on individual thematic areas. The content of each chapter is the description of the current state of affairs, the goal at a national and EU level, and the tools for implementing these goals. The second strategic document is the "Report on the state of affairs in the area of internal security and public order in the Czech Republic in 2015 (in comparison to 2014)" (Czech Zpráva o situaci v oblasti vnitřní bezpečnosti a veřejného pořádku na územi České republiky v roce 2015 [ve srovnáni s rokem 2014]) [14]. This document was published by MICR in 2016. The department responsible for realizing the document was the Security Policy and Crime Prevention Department's Strategy and Analysis Division. This strategic document has a total of 114 non-normalized pages and is divided into two main blocks - "The development of individual types of crime and security risks" (Czech Vývoj jednotlivých druhu trestné činnosti a bezpečnostnich rizik) and "Policy in the area of internal security and public order" (Czech Politika v oblasti vnitřni bezpečnosti a veřejného pořádku). These two main chapters are preceded by a summary chapter. The final strategic document is the "EMN annual report on asylum and migration policy 2015" (Czech EMN výroční zpráva o politice $v$ oblasti azylu a migrace 2015) [15], which was published in 2016 by MICR but was actually processed by the Czech European Migration Network Contact Point [Czech České národni kontaktni misto Evropské migračni sitè]. The annual report has 84 non-normalized pages and records developments in specific areas of migration, existing legislation, statistics on legal and illegal migration, and the forms of repatriation policy.

As the second segment, legislative public documents are represented by two draft laws. The first is the "Government Bill on the Protection of the State Borders of the Czech Republic and the Amendment of Related Laws" (2015) (Czech Vládní návrh zákona o ochranè státních hranic České republiky a o změně souvisejicich zákonü [2015]) [16] and the second includes the Government Bill Amending Act. no 325/1999 Coll. on Asylum as Amended, Act. 326/1999 on the Residence of Foreign Nationals in the Czech Republic and Amending Certain Other Acts, and Act no. 221/2003 Coll. on the Temporary Protection of Foreign Nationals, as Amended and other Related Laws (Czech Vládní návrh zákona, kterým se mění zákon č. 325/1999 Sb., o azylu, ve znění pozdějšich předpisů, zákon č. 326/1999 Sb., o pobytu cizinců na územi České republiky a o změně některých zákonů, ve znění pozdějššch předpisů, zákon č. 221/2003 Sb., o dočasné ochraně cizincư, ve znění pozdějších předpisü, a dalši souvisejici zákony) [17]. The first bill has 42 pages, while the second has 212 . Both bills also contain argumentative reports that are substantial for the justification of proposed amendments or of wholly new wording in these laws.

Press releases make up the final sphere of analyzed documents and are divided into four subcategories according to the year of their publication. The occurrence of studied expressions was recorded in a total of nine press releases, four from 2014, two from 2015, and three from 2016. As of March 2017, no press release has been printed containing the studied expressions. 


\subsection{Results in Public Documents Dealing with Strategy (Including Reports on Policy Implementation)}

In the field of strategic documents (including implementation reports), the following documents were analyzed: The Migration Policy Strategy of the Czech Republic [18], the Report on the state of affairs in the area of internal security and public order in the Czech Republic in 2015 (in comparison to 2014) [14], and the EMN annual report on asylum and migration policy 2015 [15].

Tab. 1: Summary of number of occurrences in strategic public documents

\begin{tabular}{|l|c|c|c|c|c|c|}
\hline & $\begin{array}{c}\text { Security } \\
\text { and } \\
\text { migration } \\
\text { (in general) }\end{array}$ & $\begin{array}{c}\text { Protection } \\
\text { and Control } \\
\text { of EU } \\
\text { borders }\end{array}$ & $\begin{array}{c}\text { Border } \\
\text { controls in } \\
\text { the Czech } \\
\text { Republic }\end{array}$ & $\begin{array}{c}\text { Cross- } \\
\text { border } \\
\text { crime }\end{array}$ & $\begin{array}{c}\text { Internal } \\
\text { security } \\
\text { (without } \\
\text { direct link to } \\
\text { migration) }\end{array}$ & $\begin{array}{c}\text { Overall } \\
\text { number of } \\
\text { occurrences }\end{array}$ \\
\hline $\begin{array}{l}\text { Migration Policy } \\
\text { Strategy of the Czech } \\
\text { Republic }\end{array}$ & 3 & 1 & 0 & 0 & 0 & 4 \\
\hline $\begin{array}{l}\text { Report on the state of } \\
\text { affairs in the area of } \\
\text { internal security and } \\
\text { public order in the } \\
\text { Czech Republic in } \\
\text { 2015 (in comparison } \\
\text { to 2014) }\end{array}$ & 3 & 3 & 1 & 7 & 4 & 18 \\
\hline $\begin{array}{l}\text { EMN annual report } \\
\text { on asylum and } \\
\text { migration policy 2015 }\end{array}$ & 0 & 0 & 0 & 0 & & \\
\hline
\end{tabular}

Source: Own research

The highest frequency of the studied expressions was recorded in the Report on the state of affairs in the area of internal security and public order in the Czech Republic in 2015 (in comparison to 2014) in the code of "cross-border crime" (see Tab. 1). Specific constructions can be divided by meaning into individual sections. The first two constructions deal with cross-border victims of criminal activity, the second two deal with the activity of police forces in border regions in efforts to suppress drug crime and the operative function of tracking criminal offenders or their transfer. The fifth and sixth constructions are focused on street prostitution in the South Bohemia Region and the positive impact of border controls on the decrease of clients of so-called "public houses" where sexual services are provided. The seventh and the last construction dealt with the general coordination of activity between the police forces of the Czech Republic and Germany. This shows that cross-border crime was not put into the context of migration and therefore no public policy that MICR would initiate in the short-term is linked to it in a strategic sense. In the other two strategic documents, no other construction is contained in the code "cross-border crime".

The second most frequent occurrence of expressions was found with the code "internal security", again in the Report on the state of affairs in the area of internal security and public order in the Czech Republic in 2015 (in comparison to 2014). Three of four occurrences deal with security systems for heightening general internal security in civil aviation including the outer border of the Schengen Area at international airports. None of the constructions 
explicitly express a direct link to border controls with the goal of dealing with the so-called "migration crisis". There are only mentions of "new trends" and terrorism, which cannot be objectively linked to migration. The fourth and last occurrence is contextually linked to security and public order but only generally mentions the Operational Programme for Crossborder Cooperation (Czech Operační program Přshraniční spolupráce), which serves as a source for the implementation of these policies.

The Report on the state of affairs in the area of internal security and public order in the Czech Republic in 2015 (in comparison to 2014) contains other constructions in other categories. Three constructions contain the code "security and migration". Two of the three constructions deal directly with illegal migration, specifically concerning illegal residency in the Czech Republic. The document argues that there has been a "marked" rise in control activities by state security forces, specifically by $181.7 \%$. The cause of this is listed as transit migration via the territory of the Czech Republic. The phenomena that are linked to and identify the transit character of migration and the detainment of individuals classified as illegally residing are inter-annually heightened. The number of detained individuals with Syrian citizenship increased by 1319 percent, with Afghan citizenship by 825.4 percent, and Iraqi citizenship by 2418.8 percent. Checks were focused primarily on rail connections and the situation culminated in the period between July and September 2015 in connection with border controls and other political measures in neighboring states (transit migration was from Slovakia and Austria). In addition to the list of statistical data, the document also contains the evaluative viewpoint that "illegal migration is linked to the abuse of asylum procedures". The abuse of asylum procedures is backed up by statistics, specifically that 1447 individuals requested international protection in another state that is a part of the European Union. Here the reason for multiple applications for international protection is implicitly linked with the expiration of the period for leaving the Czech Republic. On the other hand, it is not wholly clear what number of individuals applied for international protection before being intercepted (detained). The third and final construction of this code deals with expressions of the urgency of the problem of security as a consequence of the migration crisis in the form of internal checks of the borders of the Schengen System (specifically these countries: Germany, Austria, Slovenia, Hungary, France, Sweden, Norway, and Denmark).

The last three constructions that were found under strategy fall under the code "protection and control of EU borders". Two of three constructions deal with border controls in the area of the internal borders of the Schengen Agreement, which have a fundamental impact on transit migration flow through the Czech Republic. After enacting higher degrees of control of the state's borders that were mentioned above, there was a strong decrease beginning in midSeptember of illegally transiting migrants through the Czech Republic. The last construction deals with the concept of "smart borders" or current negotiations regarding its form. It should be mentioned that, according to the European Commission's document "Europe without Borders", smart borders are a system that allows for the higher control of illegal migration and, contrarily, the fluidity of transit across borders for those who have undergone a preliminary check [19].

The last two documents contain occurrences only in two codes. Both cases deal specifically with the Migration Policy Strategy of the Czech Republic. The EMN annual report on asylum and migration policy 2015 does not contain any occurrences and no category marked with its own code was found in the document. In the first document, there are a total of three occurrences of the code "security and migration". In this case, migration is explicitly linked to security in the form of "new security challenges" in the protection of the population. Migration policies should be "more effective" and "more responsible" and should also be coordinated on both a national and EU level. The goal at the national level (the goal on the 
EU level is not formulated) should be the effective prevention via combating illegal migration.

\subsection{Results of Legislative Public Documents}

Legislative public documents make up a necessary part of political processes and are a formal expression of public policies. For the development of the narrative, already existing laws were not examined, but laws that have recently been proposed. The following facts make up the criteria for selection: MICR is responsible for creating bills; MICR submitted the given norm in the period studied; at least one construction occurred in the document. Thanks to these criteria, the number of legislative public documents was limited to only two documents (see Tab. 2).

Tab. 2: Summary of number of occurrences in legislative public documents

\begin{tabular}{|c|c|c|c|c|c|c|}
\hline & $\begin{array}{c}\text { Security } \\
\text { and } \\
\text { migration } \\
\text { (in general) }\end{array}$ & $\begin{array}{c}\text { Protection } \\
\text { and Control } \\
\text { of EU } \\
\text { borders }\end{array}$ & \begin{tabular}{|c} 
Border \\
controls in \\
the Czech \\
Republic
\end{tabular} & \begin{tabular}{|l|} 
Cross- \\
border \\
crime
\end{tabular} & \begin{tabular}{|c|} 
Internal \\
security \\
(without \\
direct link to \\
migration) \\
\end{tabular} & $\begin{array}{c}\text { Overall } \\
\text { number of } \\
\text { occurrences }\end{array}$ \\
\hline $\begin{array}{l}\text { Government Bill on } \\
\text { the Protection of the } \\
\text { State Borders of the } \\
\text { Czech Republic and } \\
\text { the Amendment of } \\
\text { Related Laws (2015) }\end{array}$ & 1 & 10 & 66 & 0 & 5 & 82 \\
\hline $\begin{array}{l}\text { Government Bill on } \\
\text { the Residency of } \\
\text { Foreign Nationals and } \\
\text { their Temporary } \\
\text { Protection (including } \\
\text { argumentation report; } \\
2015 \text { ) }\end{array}$ & 0 & 0 & 2 & 0 & 0 & 2 \\
\hline
\end{tabular}

Source: Own research

When at first we compare both documents [16, 17], it is clear that in the first there is substantially more occurrences of the studied expressions, which may be surprising in regard to the proportionality of both bills as the second is significantly longer. On the other hand, the mere title of the bills shows that the first document is a better thematic representation of the studied expressions.

In the government bill [16] dealing with the protection of borders, there are matches in all categories except one, which is "cross-border crime". Most occurrences appear in the category of "border controls in the Czech Republic" - a total of 66. The code of border controls, however, can be specified more narrowly, as most of the occurrences deal with the operational deployment of security forces and other provisions of a technical character. As an example, we cite the following: "for purposes of protecting internal borders, a police officer within 10 kilometers of the internal borders is authorized to enter other properties than publicly accessible properties in cooperation with its owner or authorized user" or "during the temporary reinstatement of the protection of internal borders, the police are authorized to use technical means to prevent the illicit crossing of internal borders using means of transport". There are a total of sixty such constructions. Checks in the sense of border protection are mentioned in only ten cases, while four of them deal with the international 
airport in terms of border crossing between the Czech Republic and third countries (the Czech Republic does not have a border with third countries elsewhere than at its international airport). The first four constructions deal with the necessity to divide passengers at international airports into two groups - travelers from third countries (a zone must be established to check them) and travelers moving within the Schengen Zone.

The second and third construction elaborate on the rule regarding the necessity of zones for carrying out traveler control also on internal flights in the case that internal border controls are reinstated. The second and third constructions react to the migration crisis and the measures of other states that limit entry to their territory. The form of implementation builds on the strategy of instating smart borders, but also prepares for border controls inside the Schengen Area. The fourth construction anticipates the necessity to react to the new migration situation, as the specific conditions for instating such a zone is linked to the Ministry's decree. All four mentioned occurrences react to the new situation and instate the possibility for double checks in terms of smart borders and the creation of an environment for heightened executive power, in which it is possible to apply the Ministry's decree to modify the conditions of border controls also within the internal borders of the Schengen System. Proof of these efforts can also be found in two additional occurrences of this code, in which paragraph 12 of the bill states that: "In the event of an imminent and grave threat to public order or internal security, the Ministry may use exceptional measures to temporarily instate the protection of internal borders". This provision does not specify what threat is involved and the concept of this threat is thus linked exclusively to MICR's concept of the existence or non-existence of such a threat. MICR is also responsible for determining the extent of such measures: "The exceptional measure of the Ministry establishes the extent of time and territory of the temporary instatement of the protection of internal borders and the method of ensuring the protection of internal borders". The other occurrences specify offences during this temporary reinstatement of internal border protection. For example, an offence takes place when someone avoids a check at the place that has been designated for it. The eighth occurrence was found in the explanatory section of this act and is similarly specific as the previous construction.

The Ministry as an actor of executive power and based on the legislation mentioned above reserves the right to instate measures ranging from random checks, profiling passengers, and systematically controlling all travelers to forbidding transit over "green" borders. Information on the extent of border controls is provided by the police to municipalities located near the border. The final construction refers to offences that have already been mentioned above.

The second code, with the occurrence of ten constructions, is "protection and control of EU borders". Contexts in terms of the occurrence of this code elaborate on the previously mentioned context of internal border protection and the mechanisms for checking individuals. In this case, however, they are linked directly to the Schengen System on an EU level. Some of the codes generally react to the internal protection of the Schengen Zone in connection to the previously mentioned protection of Czech space; the majority of them (eight in total), however, react to the Schengen Border Code. The first two occurrences deal with offences made by pilots in the area of continuing a flight across a transit space or taking off from this space (for example a Czech airport) to a non-member state while violating other specially regulated conditions (for example orders to land). The fourth code expresses the complementarity of the Schengen Border Code with Czech law or with the analyzed bill. This government bill must be in full conformity with EU law. However, in areas that are not dealt with by the Schengen Border Code, MICR as the proposer reserves the right to make its own detailed arrangements. The principle of complementarity, however, must be preserved. The Schengen Border Code must be respected also in cases where security is at risk. Such cases 
are understood as exceptional situations and for this reason the norm allows for the temporary protection of internal borders to be instated. The justification, which contains the next substantial occurrence, adds that there is no clear agreement as to the actor who can carry out such temporary protection. For these reasons, the law specifies the government as the body which decides on whether to accept the policy of temporary internal border protection. If the situation calls for it, MICR can instate exceptional measures on the borders but these measures may be cancelled by a government measure of a general character. In any case, time limits set down in the Schengen Border Code must be adhered to.

The third code of the analyzed document is "internal security", which is not directly linked with the phenomenon of migration. In this case, there are five constructions in the document, none of which, however, are specific in their wording and only refer to other passages of the bill that do not coincide with the studied expressions. One specific occurrence can be mentioned with the code "security and migration" in which security is directly linked to the security inside the Schengen System and implemented via measures for the protection of the borders of Slovenia, Germany, and Austria.

The second legislative public document, the Government Bill on the Residency of Foreign Nationals and their Temporary Protection [17], contains a total of two occurrences, both with the code "border controls in the Czech Republic". The first occurrence deals with providing information to all those applying for international protection concerning their status and the method in which they should submit an application. The second occurrence is linked to the first and specifies that such protection is possible only for individuals at international airports, because this is the only area where the Czech Republic has an established border crossing with third countries. This rule thus assumes a state without exceptional measures.

\subsection{Results in MICR Press Releases (Media Representation of the Narrative)}

Press releases are included as the final section of the analyzed empirical corpus (see Tab. 3). Statements contained in press releases make up a necessary part of research, as they provide a complex picture of the framing of the problem in linguistic phrases and their contexts, which speakers - in this case representatives of MICR - use. As mentioned above, this section follows the occurrence of expressions in press releases from the beginning of 2014 to March 2017.

In the press releases from 2014, a total of eleven occurrences appear, two of which can be recorded under the code "protection and control of EU borders". The first occurrence deals with police cooperation between Austria and the Czech Republic in order to ensure a higher degree of security [20]. One positive element is the exchange of information on risks in border regions and coordination of potential mutual action. In the cooperation agreement, the newly established (and also updated) rules increase the quality of ensuring security. The second recorded occurrence deals with the temporary establishment of border controls in Belgium in connection with the G7 Summit. The establishment of checks is directly interpreted as a measure to heighten security. The check is a tool with the goal of "... preventing the entry of those individuals who may present a serious threat to domestic security" [21]. Press releases from 2014 contain one occurrence in the code of "border controls in the Czech Republic". In terms of context, this occurrence is linked to a new cooperation agreement between the Czech Republic and Germany which, according to MICR, was necessary, as the need increased for the mutual coordination of police forces (external space became domestic space) [20] after border controls were cancelled (upon the Czech Republic's entrance into the Schengen Zone). "Cross-border crime" is the third code in which occurrences appear in the press releases of 2014. All codes are linked to common crime without a direct link to migration. There are mentions of drug crime, auto theft, and a proposal 
to strengthen the camera systems in border regions [20,22]. The code "internal security" contains three occurrences that contain only general declarations such as cooperation between individual regions and the state (in the form of MICR), security coordination with Austria, and the stabilization of security forces for heightening the degree of security in the Czech Republic (this occurrence explicitly mentions drug crime).

Tab. 3: Summary of the number of occurrences in press releases

\begin{tabular}{|l|c|c|c|c|c|c|}
\hline & $\begin{array}{c}\text { Security and } \\
\text { migration (in } \\
\text { general) }\end{array}$ & $\begin{array}{c}\text { Protection } \\
\text { and Control } \\
\text { of EU borders }\end{array}$ & $\begin{array}{c}\text { Border } \\
\text { controls in } \\
\text { the Czech } \\
\text { Republic }\end{array}$ & $\begin{array}{c}\text { Cross- } \\
\text { border } \\
\text { crime }\end{array}$ & $\begin{array}{c}\text { Internal security } \\
\text { (without direct } \\
\text { link to } \\
\text { migration) }\end{array}$ & $\begin{array}{c}\text { Overall } \\
\text { number of } \\
\text { occurrences }\end{array}$ \\
\hline $\begin{array}{l}\text { MICR press } \\
\text { releases in } \\
2014\end{array}$ & 0 & 2 & 1 & 5 & 3 & 11 \\
\hline $\begin{array}{l}\text { MICR press } \\
\text { releases in } \\
\text { 2015 }\end{array}$ & 3 & 11 & 1 & 0 & 0 & 15 \\
\hline $\begin{array}{l}\text { MICR press } \\
\text { releases in } \\
2016\end{array}$ & 2 & 5 & 2 & 0 & 0 & 9 \\
\hline $\begin{array}{l}\text { MICR press } \\
\text { releases up } \\
\text { to March } \\
\text { 2017 }\end{array}$ & 0 & 0 & 0 & 0 & & 0 \\
\hline
\end{tabular}

Source: Own research

Press releases from 2015 contain a total of fifteen occurrences. For the code "security and migration", we can point out declarations in which the largest problems of the European Union can be identified as terrorism and migration (both issues are divided and no connection is explicitly stated). Migration is linked to security here in the fact that strengthening the borders of the external borders of the EU is referred to as a necessity and something that must be implemented immediately. Similarly, the necessity to implement a series of measures to strengthen the role of the Frontex agency is also mentioned. The occurrence of these statements is specific in that it deals with summarizing the mutual letter written by the French and German Interior Ministers dated December 3, 2015. From this summary, and thus interpretation, we can assume that this summary contains the opinion of MICR [23]. In the interest of security, MICR also announced that the Czech Republic would be reinforcing its borders with Austria with a focus on mapping the situation of illegal immigration. In a press release, MICR states that this does not deal with the reinstatement of border controls, but concerns the strengthening of the security of Czech citizens via extending already-existing measures in accordance with the Schengen Border Code [24]. The second code, "protection and control of EU borders", contains the most occurrences with regard to the whole period of press release content analysis but also in regard to the gradual development of the frequency in the studied topics (see Fig. 1), which in and of itself expresses a greater emphasis on border protection on the part of MICR in 2015. The fundamental contextual tendency that is present in the occurrences is the strengthening of external border protection and the development of coordination in dealing with shared policies such as the Common European Asylum System, strengthening the role of the Frontex agency (primarily its powers and obligations in deploying fast-action border units), linking databases of registered individuals and developing an "Entry/Exit" system via smart borders [23]. Through its press releases, MICR also makes efforts to ensure that all measures fall within EU-level agreements, including cases in which 
the Czech Republic one-sidedly strengthens the protection of its own national borders (this is emphasized in connection with the only occurrence in the code "border controls in the Czech Republic") [24].

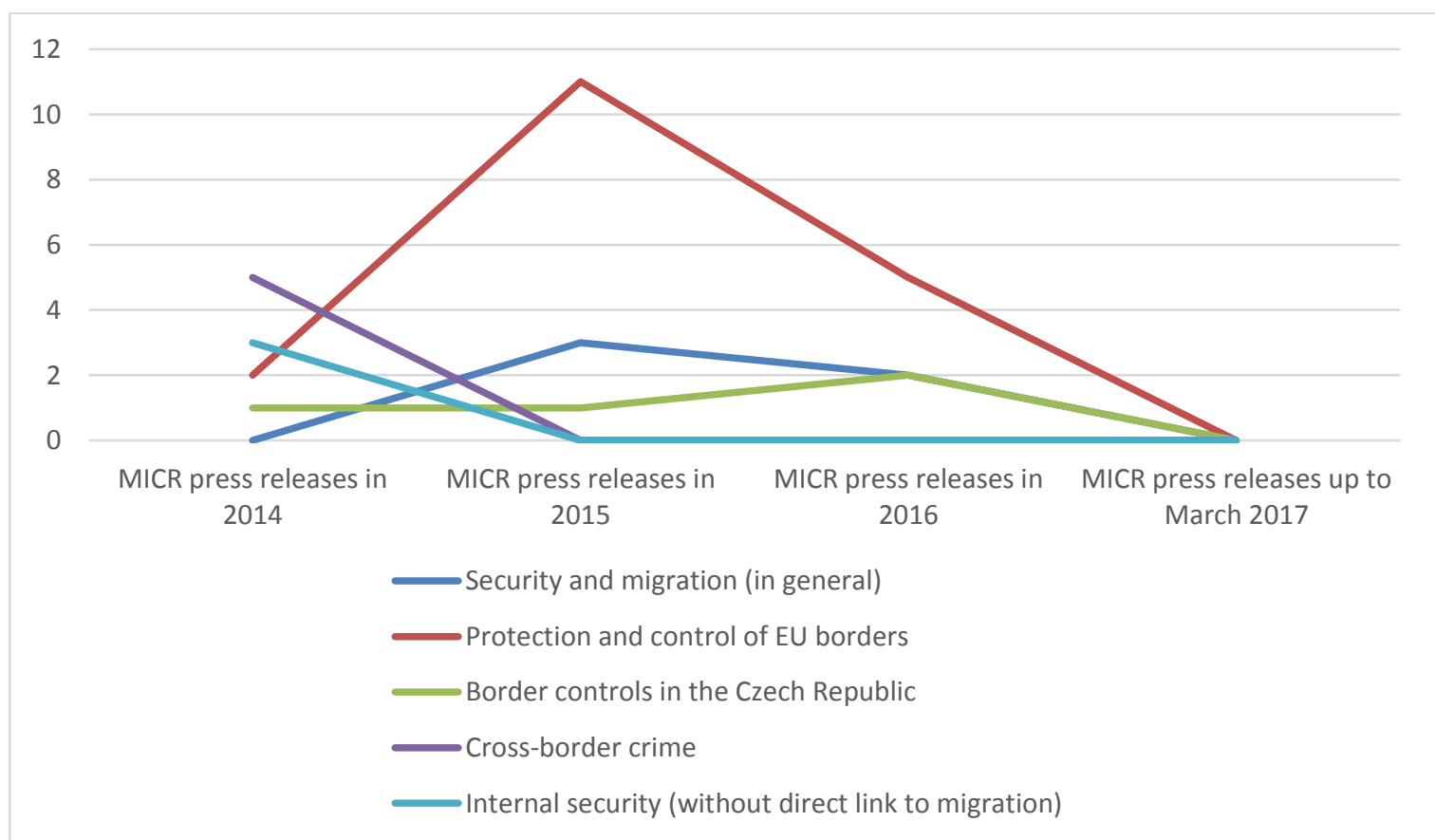

Source: Own research

Fig. 1: Visualization of topics contained in press releases

In press releases from 2016, a total of nine occurrences can be identified, the majority of which are listed under the code "protection and control of EU borders". In this code, MICR provides information on possible changes in the so-called "Dublin Regulation" (an administrative mechanism for processing the international protection requests of foreign nationals) [25], the Schengen Border Code, and the implementation of smart borders. However, there is no information on the methods of these changes; the press release merely points out the commencement of an open discussion on these issues on an EU level [26]. In addition to this general information, MICR also announced Czech police training at the borders with Slovakia, Germany, and Austria. This training was meant to strengthen "security in connection to migration" [27]. In the code "security and migration" two occurrences were recorded. In the context of the first occurrence, MICR gives information on the negotiation of the Council of EU Ministers concerning the revision of the Dublin Regulation (see above), in which it states that it welcomes the measures, which will help limit illegal migration into the EU. It also states that the redistribution mechanism of asylum seekers must be established on a voluntary basis. This voluntariness is directly mentioned in the context of security and security is mentioned as coming before voluntariness (its conditional character is mentioned). The second occurrence again gives information on Czech police training. The last code is "border controls in the Czech Republic". This code again contains the occurrence of Czech police training and is of an informative character. The last context deals with the cancellation of controls on the Czech-Bavarian border and, contrarily, the extension of controls in the interior of the country for reasons of the first degree level of a terrorist threat [28].

\section{Conclusion}

Mapping the context of the migration narrative of ensuring security in terms of the actor MICR took place via the content analysis of three types of public documents. In strategic 
public documents, several issues were dealt with that fall generally into the category of maintaining order and security, which in the Czech context falls under MICR's jurisdiction. Border and cross-border crime was not contextually linked to migration, nor were the mentions of border controls upon entry to the Czech Republic linked directly to the goal of solving the "migration crisis" (or a similar phenomenon). The strategies primarily dealt with policies concerning the movement of individuals inside the Czech Republic and thematized illegal residence in regard to "sidetracking" asylum procedures valid throughout the Schengen System. Border controls were mentioned on the level of the Schengen System in connection to the illegal movement of individuals on Czech territory. The largest problem connected to the migration crisis is thus the illegal transit movement of migrants across Czech territory, which significantly decreased after implementing controls on the borders of states that neighbor the Czech Republic (and are a part of Schengen). Specific proposals for solutions to the aforementioned issue - in connection with the migration crisis - are not given; they only contain calls for greater coordination at an EU level.

MICR's proposals regarding legislative documents are placed primarily into areas of the operation of international airports where the Czech Republic has borders with so-called "third states" (i.e. they are not a part of the Schengen Zone). In addition to this specific subject, the proposed norms (or their adaptations) devote space to smart borders, which can flexibly react to the heightening migration crisis via a double-control mechanism. In addition to external border controls, MICR can establish controls of internal borders as well. Controls of internal borders (with Slovakia, Austria, and Germany) must adhere to the Schengen Code; however, there is only mention that internal border controls may be carried out only in the case of a serious and imminent threat. What is and what is not a serious threat is then up to MICR's interpretation, although the implementation of the policy of internal border protection may be regulated by the government. The tools of control vary - from random checks to the systematic control of all travelers. MICR, however, does not declare only a repressive role. In the case of dealing with illegal residency of individuals in the Czech Republic, it also takes an informative role. In the case of asylum protection, no explicit exceptional measures are established.

In regard to media presentation, MICR's primary importance is to share information for the effective protection and monitoring of borders in the area of illegal migration. Migration in this context is of a transit character and such migration anticipates the policies that need to be applied for this supervision. In addition to camera systems, there are mentions of the Frontex agency and the necessity to strengthen its powers, changes to the Dublin Regulation, preventive training of the Czech Police, and the voluntary nature of the redistributions system of asylum seekers.

MICR's narrative is dominated by dealing with illegal migration on an EU level. Both its strategies and media presentation correspond to this. The control of internal borders and border controls are explicit tools for heightening the security of the Czech Republic. The specific tools of control are not clear, and merely include a declaration for heightening the role of camera systems and the defining of an operational space on internal borders. Although MICR declares the accord of its own policies with those of the Schengen Code, it reserves the right in legislative proposals to decide on the degree of threat to the Czech Republic and thus the selection of adequate means of border protection. In regard to the unclear declaratory position in its strategies, the implementation of such policies is problematic, as the public discussion on the legitimacy of such tools may be intentionally minimized by placing such emphasis on the security interests of the state. The general makeup of public policy creation in the field of security (in terms of the studied actor in the studied period) can be characterized in the following: MICR's narrative is of a more supervisory than repressive character and 
places minimal emphasis on the informative role of the ministry (apart from informing border villages and providing information to asylum seekers on their rights and obligations).

\section{Acknowledgements}

This paper was supported by the grant "Political order, legitimacy of political power, and the establishment of discourse: selected issues of applied political theory" (SGS-2016-030), which was provided by the University of West Bohemia in Pilsen.

\section{Literature}

[1] FIALA, P.; SCHUBERT, K.: Moderni analýza politiky. Barrister a Principal, Brno, 2000. ISBN 80-85947-50-1.

[2] HSIEH, H. F.; SHANNON, S. E.: Three Approaches to Qualitative Content Analysis. Qualitative Health Research. 2005, Vol. 15, Issue 9, pp. 1277-1288. ISSN 1049-7323. DOI: $\underline{10.1177 / 1049732305276687}$

[3] ADJEI, S. B.: Discourse Analysis: Examining Language Use in Context. The Qualitative Report. 2013, Issue 18, pp. 1-10. ISSN 1052-0147.

[4] KRIPPENDORFF, K.: Content Analysis. An Introduction to Its Methodology. Sage, London, Los Angeles, 2013. ISBN 978-1412983150.

[5] TAYLOR, G. H.: Understanding as Metaphoric, Not a Fusion of Horizons. In: Mootz, F. J.; Taylor, G. H. (eds.), Gadamer and Ricoeur. Critical Horizons for Contemporary Hermeneutics. Continuum, London and New York, 2011, pp. 104-118. ISBN 9781441156853. DOI: $\underline{10.5040 / 9781472546531 . c h-005}$

[6] GOFFMAN, E.: Frame Analysis. An Essay on the Organization of Experience. Northeastern University Press, Boston, 1986. ISBN 978-0930350918.

[7] GADAMER, H. G.: Text a interpretace. Reflexe. 2000, Issue 21, pp. 5-35. ISSN 08626901.

[8] RICOEUR, P.: The Rule of Metaphor. Routledge, London and New York, 2003. ISBN 978-0802064479.

[9] HÁJEK, M.: Čtenář a stroj. Slon, Praha, 2014. ISBN 978-80-7419-161-9.

[10] NEKOLA, M.; VESELÝ, A. (eds.): Analýza a tvorba veřejných politik. Slon, Praha, 2007. ISBN 9788086429755.

[11] ÚŘAD VLÁDY ČESKÉ REPUBLIKY: ODok: O projektu. [online]. 2017. [accessed 2017-04-28]. Available from WWW: https://www.odok.cz/o-projektu

[12] Rozhodnutí rady o zř́zení Evropské migrační sítě (2008/381/ES). In: EUR-Lex. [online]. 2008. [accessed 2017-04-28]. Available from: http://eur-lex.europa.eu/legalcontent/CS/TXT/?uri=uriserv:OJ.L_.2008.131.01.0007.01.CES\&toc=OJ:L:2008:131:T $\underline{\mathrm{OC}}$

[13] MVČR: $O$ EMN. [online]. 2017. [accessed 2017-04-28]. Available from WWW: http://www.emncz.eu/o-emn/

[14] MVČR: Zpráva o situaci v oblasti vnitřni bezpečnosti a veřejného pořádku na území České republiky v roce 2015 (ve srovnání s rokem 2014). [online]. 2016. [accessed 2017-04-28]. Available from WWW: http://www.mvcr.cz/clanek/zprava-o-situaci-voblasti-vnitrni-bezpecnosti-a-verejneho-poradku-na-uzemi-ceske-republiky-v-roce$\underline{2015 . \operatorname{aspx}}$ 
[15] MVČR: Výroční zpráva o politice v oblasti azylu a migrace 2015 (Evropská unie, MVČR a Evropská migrační sit'). [online]. 2015. [accessed 2017-04-28]. Available from WWW: http://www.emncz.eu/cinnost-a-publikace-emn/?f_category=vyrocni_zpravy

[16] ÚŘAD VLÁDY ČESKÉ REPUBLIKY: Vládní návrh Zákona o ochraně státních hranic České republiky a o změně souvisejících zákoni̊. [online]. 2015. [accessed 201704-28]. Available from WWW: https://apps.odok.cz/veklepdetail?pid=KORN9QEJ3XL7

[17] ÚŘAD VLÁDY ČESKÉ REPUBLIKY: Vládní návrh zákona, kterým se mění zákon č. 325/1999 Sb., o azylu, ve zněni pozdějšich predpisů, zákon č. 326/1999 Sb., o pobytu cizinců na územi České republiky a o změně některých zákonů, ve znění pozdějšich předpisü, zákon č. 221/2003 Sb., o dočasné ochraně cizincü, ve znění pozdějšich předpisů, a dalši související zákony. [online]. 2014. [accessed 2017-04-28]. Available from WWW: https://apps.odok.cz/veklep-detail?pid=KORN9NRCXV6W

[18] MVČR: Strategie migrační politiky České republiky. [online]. 2015. [accessed 2017-0428]. Available from WWW: http://www.mvcr.cz/clanek/strategie-migracni-politikycr.aspx

[19] EVROPSKÁ KOMISE: Evropa bez hranic. Schengenský prostor. [online]. 2017. [accessed 2017-04-28]. Available from http://publications.europa.eu/resource/cellar/09fcf41f-ffc4-472a-a573b46f0b34119e.0020.01/DOC_1

[20] MVČR: Ministři vnitra Česka a Rakouska podepsali Smlouvu o policejní spolupráci. [online]. 2014. [accessed 2017-04-28]. Available from WWW: http://www.mvcr.cz/clanek/ministri-vnitra-ceska-a-rakouska-podepsali-smlouvu-opolicejni-spolupraci.aspx

[21] MVČR: Belgie dočasně zavádí hranični kontroly. [online]. 2014. [accessed 2017-0428]. Available from WWW: http://wWw.mvcr.cz/clanek/belgie-docasne-zavadihranicni-kontroly.aspx

[22] MVČR: Milan Chovanec ve Zlině podpořil posílení kamerového systému v príhraničí. [online]. 2014. [accessed 2017-04-28]. Available from WWW: http://www.mvcr.cz/clanek/milan-chovanec-ve-zline-podporil-posileni-kamerovehosystemu-v-prihranici.aspx

[23] MVČR: Společný dopis francouzského a německého ministra vnitra z 3. prosince 2015 (shrnutí). [online]. 2015. [accessed 2017-04-28]. Available from WWW: http://www.mvcr.cz/clanek/spolecny-dopis-francouzskeho-a-nemeckeho-ministravnitra-z-3-prosince-2015-shrnuti.aspx

[24] MVČR: Policie posílí v sobotu ochranu hranic s Rakouskem. [online]. 2015. [accessed 2017-04-28]. Available from WWW: http://www.mvcr.cz/clanek/policie-posili-vsobotu-ochranu-hranic-s-rakouskem.aspx

[25] MVČR: Dublinský systém. [online]. 2017. [accessed 2017-04-28]. Available from WWW: http://www.mvcr.cz/clanek/dublinsky-system.aspx

[26] MVČR: Rada ministrů jednala v Lucemburku o kvótách i o revizi Dublinského systému. [online]. 2016. [accessed 2017-04-28]. Available from WWW: http://www.mvcr.cz/clanek/rada-ministru-jednala-v-lucemburku-o-kvotach-i-o-revizidublinskeho-systemu.aspx 
[27] MVČR: MV urychluje plánovanou koordinaci systémové ochrany měkkých cílů. [online]. 2016. [accessed 2017-04-28]. Available from WWW: http://www.mvcr.cz/clanek/mv-urychluje-planovanou-koordinaci-systemove-ochranymekkych-cilu.aspx

[28] MVČR: Komentár̆ ministra vnitra po zasedání zpravodajské skupiny: bezpečnostní opatření v ČR jsou dostačující. [online]. 2016. [accessed 2017-04-28]. Available from WWW: $\quad$ http://www.mvcr.cz/clanek/komentar-ministra-vnitra-po-zasedanizpravodajske-skupiny-bezpecnostni-opatreni-v-cr-jsou-dostacujici.aspx

[29] HABERMAS, J.: Tř́i normativní modely demokracie. In: Habermas, J.; Shapiro, I. (eds.), Teorie demokracie dnes. Filosofie, Praha, 2002, pp. 79-95. ISBN 80-7007-1567.

[30] LACLAU, E.; MOUFFE, Ch.: Hegemony and Socialist Strategy. Towards a Radical Democratic Politics. Verso, London, 2001. ISBN 1859843301.

[31] HAYEK, F. A.: Právo, zákonodárství a svoboda. Nový výklad librálních principů spravedlnosti a politické ekonomie. Prostor, Praha, 2011. ISBN 978-80-7260-253-7.

[32] ROTHBARD, M. N.: Man, Economy, and State. Ludwig von Mises Institute, Auburn, 2009. ISBN 1933550279.

[33] MURPHY, R. F.: Úvod do kulturní a sociální antropologie. Slon, Praha, 2004. ISBN 978-80-86429-25-0.

[34] FISHER, F.: Reframing Public Policy. Discoursive Politics and Deliberative Practises. Oxford University Press, Oxford, 2003. ISBN 0-19-924263-1.

[35] FAIST, T.: The Migration-Security Nexus: International Migration and Security Before and After 9/11. In: Bodemann, Y. M.; Yurdakul, G. (eds.), Migration, Citizenship, Ethnos. Palgrave Macmillan, New York, 2006, pp. 103-119. Online ISBN 978-1-40398467-8. Print ISBN 978-1-349-53265-0. DOI: $\underline{10.1057 / 9781403984678 \_6}$

[36] ADAMSON, F. B.: Crossing Borders: International Migration and National Security. International Security. 2006, Vol. 31, Issue 1, pp. 165-199. ISSN 0162-2889. DOI: $10.1162 /$ isec.2006.31.1.165

[37] DeBARDELEBEN, J. (ed.): Soft or Hard Borders?: Managing the Divide in an Enlarged Europe. Routledge, London and New York, 2005. ISBN 0754643387.

[38] KING, D.; GALÉS, P. L.; VITALE, T.: Assimilation, Security, and Borders in the Member States. In: King, D.; Galés, P. L. (eds.), Reconfiguring European States in Crisis. Oxford University Press, Oxford, 2017, pp. 428-450. ISBN 9780198793373. DOI: 10.1093/acprof:oso/9780198793373.003.0022

[39] JONES, R.; JOHNSON, C.; BROWN, W.; POPESCU, G.; PALLISTER-WILKINS, P; MOUNTZ, A.; GILBERT, E.: Interventions on the state of sovereignty at the border. Political Geography. 2017, Vol. 59, pp. 1-10. ISSN 0962-6298. DOI: $\underline{10.1016 / \text { j.polgeo.2017.02.006 }}$

[40] WALDINGER, R.: A Cross-border Perspective on Migration: Beyond the Assimilation/Transnationalism Debate. Journal of Ethnic and Migration Studies. 2017, Vol. 43, Issue 1, pp. 3-17. ISSN 1369-183X. DOI: $\underline{\text { 10.1080/1369183X.2016.1238863 }}$

PhDr. Ondřej Stulík, Ph.D. 


\section{ANALÝZA VEŘEJNÉ POLITIKY OCHRANY HRANIC V BEZPEČNOSTNÍ AGENDĚ MINISTERSTVA VNITRA ČR (OD ROKU 2014 DO BŘEZNA 2017)}

Článek se zabývá bezpečnostní veřejnou politikou v České republice. Aktérů promlouvajících do tohoto druhu politik je v České republice mnoho, nicméně dle obecného povědomí a exekutivních pravomocí vyplývajících z právní úpravy je jednou z důležitých institucí Ministerstvo vnitra České republiky (MVČR). Tento aktér je odpovědný nejen za vykonávání své exekutivní role, ale v České republice má i značnou roli při př́pravě legislativních veřejných dokumentů. Článek se zaměřuje na tvorbu a kontextuální rámování narativa MVČR v aktuální otázce tzv. migrační krize, a to od vzniku současné vlády, až do března roku 2017. Konkrétně jsou sledovány kontextuální vazby vztažené k politice ochrany hranic a smyslu hraničních přechodi̊ jako bezpečnostních prvků pro zajištování vnitřní bezpečnosti ČR. Smyslem článku je popsat a konceptualizovat pozice MVČR při vytváření veřejných politik ochrany hranic, protože kontext daný takovou tvorbou vytváŕí normativní podobu vlastních priorit pro př́padnou veřejnou diskuzi a kontrolu veřejných institucí.

\section{ANALYSE DER ÖFFENTLICHEN POLITIK IN DER GRENZSICHERHEITSAGENDA DES INNENMINISTERIUMS IN DER TSCHECHISCHE REPUBLIK (VON 2014 BIS MÄRZ 2017)}

Der Artikel beschäftigt sich mit der Sicherheitspolitik in der Tschechischen Republik. Es gibt viele Akteure in der Tschechischen Republik, die verschiedene Arten der Politik beeinflussen können; aber was das allgemeine Bewusstsein und auch die rechtliche Ausgestaltung betrifft, ist das Ministerium des Inneren einer der wichtigsten Akteure. Dieser Akteur ist nicht nur für Leistung der Exekutivgewalt verantwortlich, sondern spielt auch eine wichtige Rolle bei der Vorbereitung von Legislativdokumenten. Dieser Artikel befasst sich mit der Gestaltung und der Kontextfassung der Narrativen des Ministeriums, die mit der aktuellen Thematik der Migrationskrise verbunden sind. In diesem Artikel werden vor allem die Verbindungen zwischen dem Ministerium des Inneren und der Grenzschutzpolitik ausführlich analysiert. Es kommt hier auch die Frage auf, ob die Grenzkontrollpunkte als Sicherheitselement der inneren Sicherheit in der Tschechischen Republik aufgefasst werden können. Ein Zielpunkt des Artikels ist die Beschreibung der Stellung und der Möglichkeiten des Ministeriums des Inneren im Bereich der Bildung der Grenzschutzpolitik.

\section{ANALIZA POLITYKI PUBLICZNEJ W ZAKRESIE OCHRONY GRANIC W SPRAWACH DOTYCZACCYCH BEZPIECZEŃSTWA PODEJMOWANYCH PRZEZ MINISTERSTWO SPRAW WEWNĘTRZNYCH REPUBLIKI CZESKIEJ (OD 2014 ROKU DO MARCA 2017 ROKU)}

Artykuł poświęcony jest polityce publicznej w zakresie bezpieczeństwa w Republice Czeskiej. W Republice Czeskiej jest wiele instytucji zajmujących się tego rodzaju polityką, jednak patrząc na ogólną wiedzę i kompetencje wynikające $\mathrm{z}$ przepisów prawa jedną $\mathrm{z}$ ważnych instytucji jest Ministerstwo Spraw Wewnętrznych Republiki Czeskiej. To instytucja odpowiedzialna nie tylko za wykonywanie swojej roli egzekwującej, ale w Republice Czeskiej ma także znaczącą rolę w zakresie przygotowywania dokumentów legislacyjnych. W artykule skupiono się na działaniach Ministerstwa Spraw Wewnętrznych Republiki Czeskiej podejmowanych w sprawie aktualnego problemu tzw. kryzysu migracyjnego, analizując to od momentu powstania obecnego rządu do marca 2017 roku. Analizie poddane są kontekstualne zależności dotyczące polityki ochrony granic i sensu istnienia przejść granicznych jako elementów zapewniających bezpieczeństwo wewnętrzne Republiki Czeskiej. W artykule opisano i koncepcyjnie przedstawiono rolę Ministerstwa Spraw Wewnętrznych Republiki Czeskiej w tworzeniu polityki publicznej w zakresie ochrony granicy, ponieważ na tym oparty kontekst stwarza normatywną formę własnych priorytetów pod kątem ewentualnej dyskusji publicznej i kontroli instytucji publicznych. 